\section{PELATIHAN PENERAPAN \\ TEKNIK FUN GAME PADA \\ GURU GURU BAHASA \\ INGGRIS PAUD \\ KECAMATAN BENGKALIS}

\author{
Erni Erni' \\ I)Universitas Riau \\ * Erni Erni \\ Email: erni@lecturer.unri.ac.id
}

\section{Abstract}

Learning English in Bengkalis District, Bengkalis Regency, Riau has not achieved the expected results. The low ability of teachers to master teaching materials and techniques contributes to the low motivation, language skills, and vocabulary mastery of Kindergarten students in the Bengkalis District. The participants of this community service activity are the Kindergarten English teacher in Bengkalis District. Problem-solving through the community service activities was done. Kindergarten teachers were trained to use Fun Game techniques in teaching English. The results of community service activities through the training of Fun Games techniques increased the ability and skills of Kindergarten English teachers in teaching English. Applying the Fun Game technique in the teaching and learning process improved the English learning outcomes of kindergarten students in the Bengkalis district. By applying the Fun Game technique, the trainees were enthusiastic about learning and happy in learning English.

Keywords: Training; fun game technique; Kindergarten teachers

\begin{abstract}
Abstrak
Pembelajaran Bahasa Ingris di Kecamatan Bengkalis, kabupaten Bengkalis Riau belum mencapai hasil yang diharapakan. Rendahnya kemampuan guru dalam memguasai materi ajar dan teknik mengajar berkontribusi terhadap rendahnya motivasi, kemampuan berbahasa Inggris siswa PAUD. Untuk itu dilakukan kegiatan pengabdian kepada masyarakat melalui pelatihan teknik Fun Game. Khalayak sasaran dalam kegiatan pengabdian kepada masyarakat ini adalah guru guru Bahasa Inggris PAUD di Kecamatan Bengkalis. Pemecahan masalah adalah dengan memberi pelatihan mengajar Bahasa Inggris dengan Teknik Fun Game. Kegiatan pelatihan dilakukan selama 8 minggu. Hasil pengabdian masyarakat menujukan bahwa pelatihan dengan teknik fun game meningkatkan kemampuan dan keterampilan guru Bahasa Inggris PAUD dalam mengajar Bahasa Inggris. Dengan menerapkan teknik Fun Game dalam proses belajar mengajar dapat meningkatkan hasil belajar Bahasa Inggris siswa TK se-kabupaten Bengkalis. Dengan teknik Fun Game terbukti peserta pelatihan antusias belajar dan senang dalam mempelajari bahasa inggris.

Kata kunci: pelatihan; tehnik fun game; guru PAUD
\end{abstract}


PELATIHAN PENERAPAN TEKNIK FUN GAME PADA GURU GURU BAHASA INGGRIS PAUD KECAMATAN BENGKALIS

Erni Erni

Volume 1, No. 1, April 2021 hal. 89-101

DOI Artikel : 10.46306/jub.v1i1.18

\section{PENDAHULUAN}

Kabupaten Bengkalis adalah salah satu dari 12 kabupaten / kota yang terletak di provinsi Riau. Di Kabupaten Bengkalis terdapat II Kecamatan yaitu Bengkalis, Bantan, Bukit Batu, Mandau, Rupat, Rupat Utara, Siak Kecil, Pinggir, Bandar Laksamana, Talang Muandau, Bathin Solapan. Di kabupaten Bengkalis ini, terdapat beberapa sekolah mulai dari tingkat PAUD, SD, SMP hingga SMA baik yang dimiliki oleh pemerintah maupun swasta. Di kabupaten Bengkalis terdapat sebanyak 216 PAUD yang semua nya dikelolah oleh swasta dan 54 PAUD dengan jumlah guru sebanyak I4 laki laki dan 288 perempuan di Kecamatan Bengkalis (DISKOMINFO 2019). Terdapat sebanyak 47 orang guru Bahasa Inggris yang mengajar pelajaran Bahasa Inggris dasar pada sekolah PAUD.

Pelaksanaan pembelajaran Bahasa Inggris dilakukan satu kali dalam seminggu dengan jumlah waktu tatap muka 2 jam pelajaran (JP). Materi pembelajaran difokuskan pada pengenalan benda benda sekitar dan daily expression termasuk greetings. Sistem pembelajaran di kelas dilaksanakan oleh guru dengan metode demonstrasi, pemberian contoh, dan praktek sederhana penguasaan kosa kata.

Pembelajaran Bahasa Ingris di sekolah PAUD dapat di simpulkan sebagai pembelajaran yang kurang sukses. Ini terbukti dari hasil nilai raport siswa pada pelajaran Bahasa Inggris yang tergolong rendah dengan range 4,5 - 7,5. Hasil observasi dan interview terhadap beberapa siswa dilapangan, ditemui bahwa siswa PAUD belum bisa berkomunikasi Bahasa Inggris sederhana sehari - hari dengan baik. Penguasaan vocabulary (kosa kata) siswa masih tergolong sangat rendah. Ini terlihat dari hasil tes/ulangan harian lisan dan tulisan yang diberikan guru di setiap pokok bahasan dan pada ujian semester.

Kegagalan pembelajaran Bahasa Inggris di PAUD ini menjadi tanggung jawab semua sivitas akademi di Propinsi Riau. Melalui kegiatan Pengabdian pada Masyarakat, praktisi pendidikan bertanggung jawab dalam meningkatkan kualitas sumber daya manusia termasuk guru. Untuk tingkat Pendidikan terendah seperti PAUD, guru guru perlu dibekali keterampilan teknik mengajar yang menyenangkan yang lebih dikenal dengan metode Joyful Learning. Maka dari itu dilaksanakanlah kegiatan pengabdian masyarakat dalam bentuk pelatihan metode mengajar Fun Game bagi guru Bahasa Inggris tingkat PAUD yang dikenal dengan Fun Games and Activities for Teaching English for youmg learners. Belajar bahasa Inggris dengan game MMORPG meningkatkan kemampuan mendengarkan, membaca, dan menulis, dan motivasi belajar, serta keterampilan komunikatif (Suh et al., 2010).

Ada beberapa masalah yang teridentifikasi dalam pelaksanaan pembelajaran Bahasa Inggris di PAUD anatar lain: Rendahnya kemampuan siswa dalam menggunakan ungkapan tindak tutur Bahasa Inggris dalam berbicara/ speaking sederhana sehari - hari. Rendahnya listening comprehension (kemampaun menyimak) menggunakan ungkapan tindak tutur sederhana. Rendahnya kemampuan menulis kalimat sederhana menggunakan kosa kata sehari hari dengan benar. Kurangnya motivasi siswa untuk belajar dan menggunakan Bahasa Inggris sederhana di dalam kelas dan lingkungan sekitar. Siswa kurang bergairah dan kurang aktif dalam belajar bahsasa Inggris sederhana. 
PELATIHAN PENERAPAN TEKNIK FUN GAME PADA GURU GURU BAHASA INGGRIS PAUD KECAMATAN BENGKALIS

Erni Erni

Volume 1, No. 1, April 2021 hal. 89-101

DOI Artikel : 10.46306/jub.v1i1.18

Tujuan pelatihan Teknik Fun Games adalah untuk meningkatkan kemampuan dan keterampilan guru dalam menerapkan metode mengajar yang aktif, inovative, kreatif dan menyenangkan, dan mengajarkannya pada siswa PAUD sehingga siswa mampu berbahasa Inggris sederhana sehari hari. Metode Fun Game telah terbukti dapat meningkatkan kemampuan berbahsa Inggris siswa untuk tingkat Dasar (Erni (2007). Ada dua tujuan yang dicapai denagn pelaksanaan kegiatan pengabdian kepada masyarakat yaitu: Setelah memperoleh pelatihan tentang keterampilan berbahasa Inggris dengan Teknik Fun Games, pengetahuan dan keterampilan guru Bahasa Inggris PAUD bertambah baik sehingga mengajarkan Bahasa Inggris menjadi baik dan tepat kepada siswa siswa PAUD. Keterampilan motode mengajar Bahasa Inggris yang menyenangkan (Fun Game) meningkatkan hasil belajar Bahasa Inggris siswa PAUD.

Bagi siswa PAUD, belajar berbahasa Inggris dengan teknik Fun Game dapat menghilangkan stress dan kejenuhan, dan meningkatkan motivasi dalam belajar. Siswa PAUD mampu menyerap materi pelajaran Bahasa Inggris berupa kosa kata dan ungkapan sederhana sehari hari dengan baik. Pelaksananya kegiatan Pengabdian Masyarakat ini memberi manfaat sebagi berikut: Guru Bahasa Inggris PAUD dapat menerapkan metode mengajar yang interaktif dan menyenangkan. Siswa dapat menguasai empat keterampilan berbahasa Inggris sederhana secara aktif sehingga memiliki kesipan diri yang baik untuk melanjutkan pendidikan ke tingkat selanjutnya yaitu sekolah Dasar (SD). Sekolah dalam melaksanakan kurikulum untuk terus berkembang menjadi sekolah yang lebih berkualitas dan menuju sekolah terakreditasi nasional dan internasional. Pendidikan di Indonesia dalam mengembangkan kualitas pendidikan Nasional menuju pendidikan bertaraf international.

Pembelajaran dengan metoda yang menarik dan menyenangkan memang terbukti mampu meningkatkan hasil belajar siswa. Dalam kegiatan belajar mengajar di kelas , guru dituntut untuk mampu memilih, mangadaptasi, mengkreasikan modek model pembelajaran yang menarik dan inofatif seperti Game. Mengajar Bahasa Inggris dengan teknik games dan aktifitas yang menyenangkan sangat diperlukan dalam mengajarkan Bahasa Inggris kepada anak anak usia dini (Lander, 2018). Apabila dalam belajar siswa merasa happy, senang, maka mereka akan termotivasi untuk mengikuti pelajaran dan materi yang diajarkam guru pun diserap dengan baik oleh siswa.

Menurut Agoestyowati (2010), Fun Game Activities dapat diterapkan dalam mengajar untuk siswa PAUD berupa Action Mime, Bingo, Simon Says, Ridles dan Guessing with one words. Action Mime dapat diterapkan untuk meningkatkan kemampuan siswa dalam menggunakan kalimat bahasa Inggris sederhana dengan tepat. Bingo lebih cocok digunakan untuk mengajarkan kosa kata atau juga untuk meningkatkan listening comprehension siswa sekolah dasar. Simon Say lebih cocok digunakan untuk penguasaan kosa kata, writing dan speaking skill. Sementara Riddles lebih cocok digunakan untuk penguasaan kosa kata dan speaking yang lebih bervariasi. Sementara Guessing with one words dapat 
PELATIHAN PENERAPAN TEKNIK FUN GAME PADA GURU GURU BAHASA INGGRIS PAUD KECAMATAN BENGKALIS

Erni Erni

Volume 1, No. 1, April 2021 hal. 89-101

DOI Artikel : 10.46306/jub.v1i1.18

digunakan untuk memperkaya kosa kata siswa level dasar untuk kemampuan berfikir dan analisis lebih tinggi).

Pada kegiatan awal pembelajaran, teknik permainan (Game) dapat digunakan sebagai motivasi dan apersepsi untuk menghangatkan suasana kelas sebelum masuk pada kegiatan inti pembelajaran. Pada kegiatan inti pembelajaran Teknik game secara tidak langusung berfungsi memberi istirahat kepada siswa ketika guru menyampaikan subjek yang sulit. Ada banyak game yang dapat diterpakan guru pada kegiatan akhir pembelajaran. Kegiatan akhir pembelajaran merupakan waktu yang digunakan oleh guru untuk menyelesaikan, menyimpulkan, merefleksi, dan mengevaluasi materi ajar. Teknik Game dapat digunakan pada kegiatan evaluasi misalnya untuk menguji kosakata, berlatih berbicara, belajar tata Bahasa sehingga menurunkan tingkat stress atau ketegangan dalam ujian (Lander, 2018).

Selanjutnya, Lander (2018) mengemukakan 10 game favorit yang disukai oleh anak anak usia dini dalam belajara Bahasa Inggris. Adapun 10 game tersebut adalah: Board Race, Call My Bluff / Two Truths and A Lie, Simon Says, Word Jumble Race, Hangman, Pictionary, The Mime, Hot Seat, Where Shall I Go?, What's My Problem?. Uberman (1998) dalam studi nya menyimpulkan bahwa mengajar Bahasa Inggris dengan teknik Game membuat para siswa antusias dalam belajar dan membangun rasa percaya diri siswa. Belajar dengan Game tidak hanya menyenangkan, akan tetapi siswa juga mampu menganalisis dan secara tidak sadar mereka telah menjadi pengguna bahasa yang sedang dipelajari dan inilah yang dinamkan communicative competemnce

\section{METODE PENGABDIAN}

I. Kerangka Pemecahan Masalah.

Masalah yang dihadapi oleh guru - guru Bahasa Inggris PAUD diatasi dengan menerapkan teknologi pelatihan teknik Fun Game. Partisipan penelitian ini berjumlah 47 orang gur Bahasa Inggris PAUD. Kerangka pemecahan masalah adalah pre test - post test design seperti ilustrasi dibawah ini:

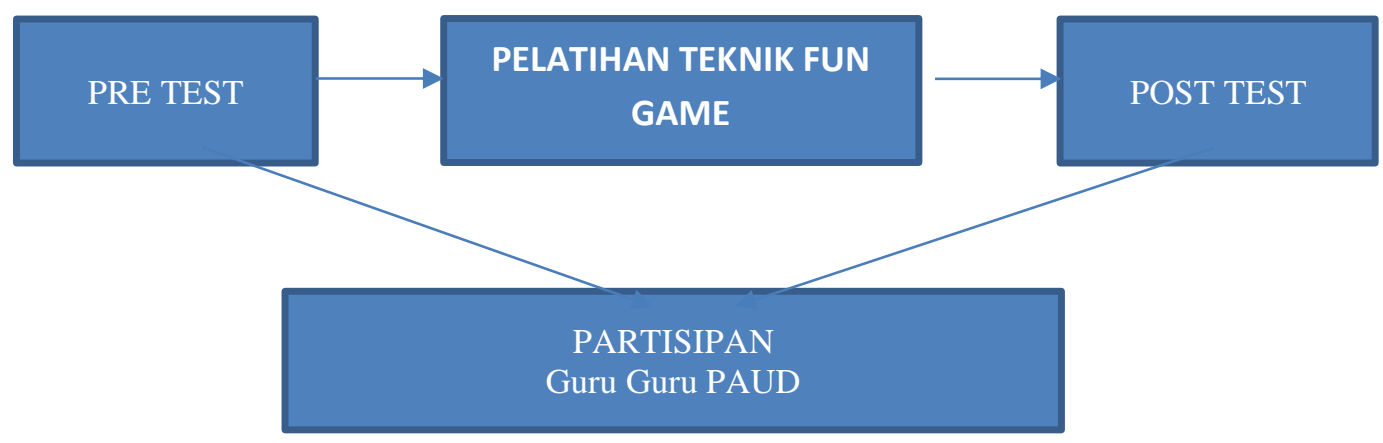

2. Khalayak Sasaran

Khalayak sasaran dalam kegiatan pengabdian kepada masyarakat ini adalah guru guru Bahasa Inggris PAUD di Kecamatan Bengkalis. Setelah mengikuti pelatihan ini, guru - guru PAUD dapat 
PELATIHAN PENERAPAN TEKNIK FUN GAME PADA GURU GURU BAHASA INGGRIS PAUD KECAMATAN

\section{BENGKALIS}

Erni Erni

Volume 1, No. 1, April 2021 hal. 89-101

DOI Artikel : 10.46306/jub.v1i1.18

mengimplementasikan pembelajaran menyenangkan, aktif, interaktif, dan komunikatif yang dapat meningkatkan berbahasa Inggris sisa siswa PAUD.

3. Realisasi Pemecahan Masalah

Beberapa faktor telah penyebab rendahnya kemampuan bahasa Inggris siswa PAUD. Salah satu faktor penyebab adalah rendahnya kemampuan guru dalam memilih dan menerapkan metoda mengajar yang aktif, inovative, kreatif dan menyenangkan (Joyfull leafning ) di kelas. Untuk mengatasi rendahnya kemampuan guru Bahasa Inggris dalam mengajar, dilakukan pelatihan mengajar Bahasa Inggris dengan Teknik Fun Game. Kegiatan pelatihan dalam bentuk pengabdian masyarakat yaitu Teknologi Pengajaran dan Teknik Game telah dilakukan penelitian sebelumnya dan terbukti hasilnya dapat meningkatkan kemampuan berbahasa Inggris guru guru PAUD.

4. Metode Pelaksanaan

Pada kegiatan pengabdian masyarakat ini, pelatihan teknik Fun Game disampaikan oleh Tim Instruktur kepada guru PAUD melalui Metacognitive Models yang dikemukakan oleh Chamot, Barnhardt dan Robbins (1999: I I-42). Teknik Fun Game yang digunakan adalah Action Mine, Bingo, Simon Says, Ridles dan Guessing with one words, Word Jumble Race, Hangman, Where Shall I Go? yang diadaptasi dari Agoestyowati (20I0), Uberman (20II), dan Fun Games and Activities for Kids (Lander, 20I8).

Kegiatan pelatihan dilakukan dalam bentuk memberi pembelajaran dengan Teknik Game. Metacognitive models ditarapkan dalam pelatihan Fun Game for Beginners untuk guru guru PAUD dalam mengajar Bahasa Inggris di PAUD di Kecamatan Bengkalis. Keunggulan metacognitive model adalah guru, dalam menerapkan learning strategy dituntut telebih dahulu memilih game yang akan digunakan berdasarkan azaz manfaat metoda dan keterpakaian metode bagi siswa di kelas (Chammot at al: 1999: II). Metacognitive models yang dilaksanakan terdiri dari empat prosedur atau process metacognitive berupa:

a. Planning strategy: meliputi kegiatan/ task: set goals, dirested attention, activate background knowledge, Predict, self-management.

b. Monitoring: meliputi kegiatan/task: ask if it makes sense, selectively attend, deductive/inductive, use management.

c. Problem Solving: meliputi kegiatan inference, ask a question to clarify, use resources,

d. Evaluating meliputi kegiatan verifying, summarize, evaluate yourself, evaluate your strategy. 
PELATIHAN PENERAPAN TEKNIK FUN GAME PADA GURU GURU BAHASA INGGRIS PAUD KECAMATAN BENGKALIS

Erni Erni

Volume 1, No. 1, April 2021 hal. 89-101

DOI Artikel : 10.46306/jub.v1i1.18

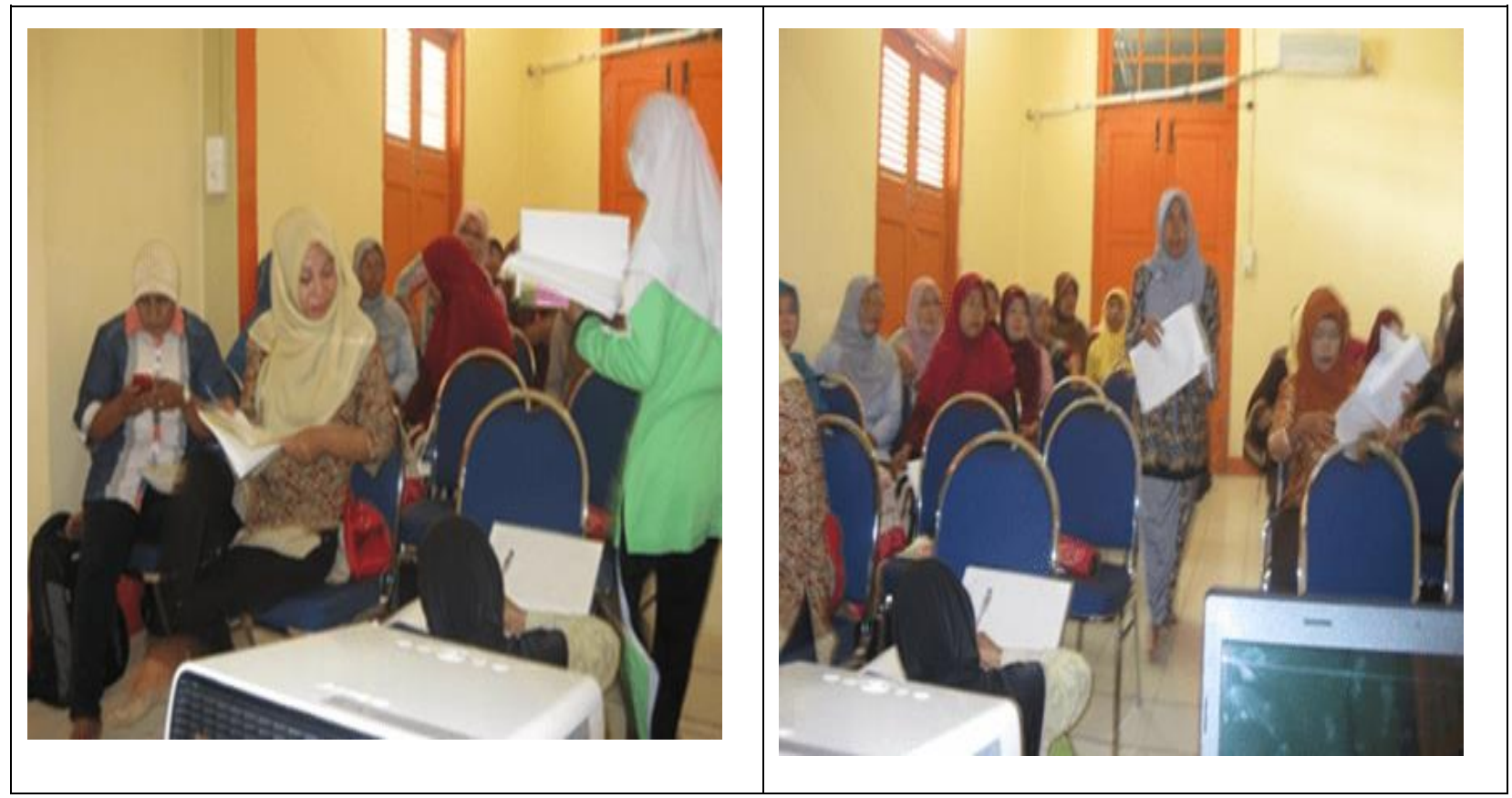

Gambar I: Kegiatan Pelatihan Penerapan Fun Game Teknik kepada guru guru PAUD

Pada kegiatan ini, peserta pelatihan (guru guru PAUD) menerapkan metacognitive model meliputi tahapan Planning, Monitoring, Problem Solving, Evaluating berdasarkan jenis Fun Game teknik yang mereka pilih untuk siswa PAUD yang mereka ajar. Materi pembelajaran difokuskan pada pengenalan kosa kata terhadap benda benda sekitar dan daily expression termasuk greetings.
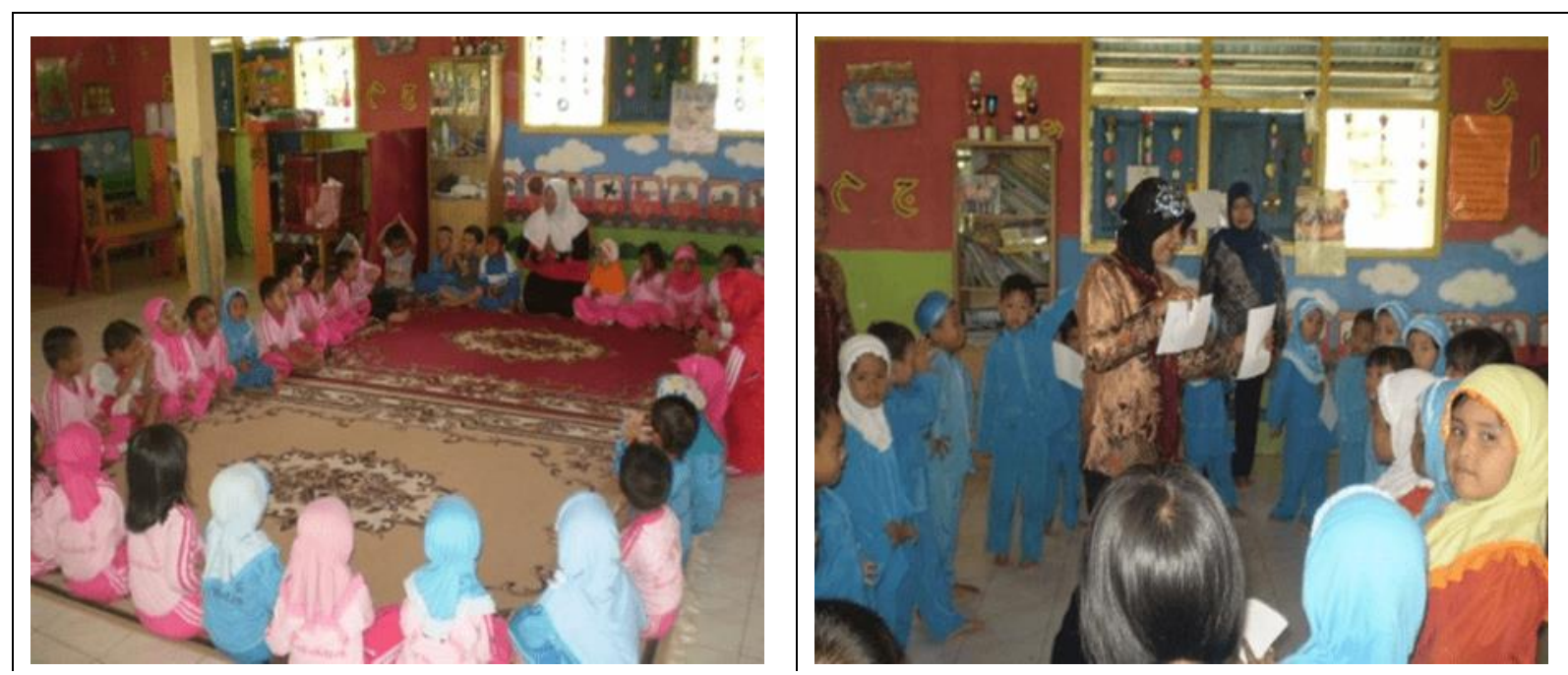

Gambar 2: Guru mengajar dengan Fun Game Teknik kepada Siswa Siswi PAUD 


\section{BENGKALIS}

Erni Erni

Volume 1, No. 1, April 2021 hal. 89-101

DOI Artikel : 10.46306/jub.v1i1.18

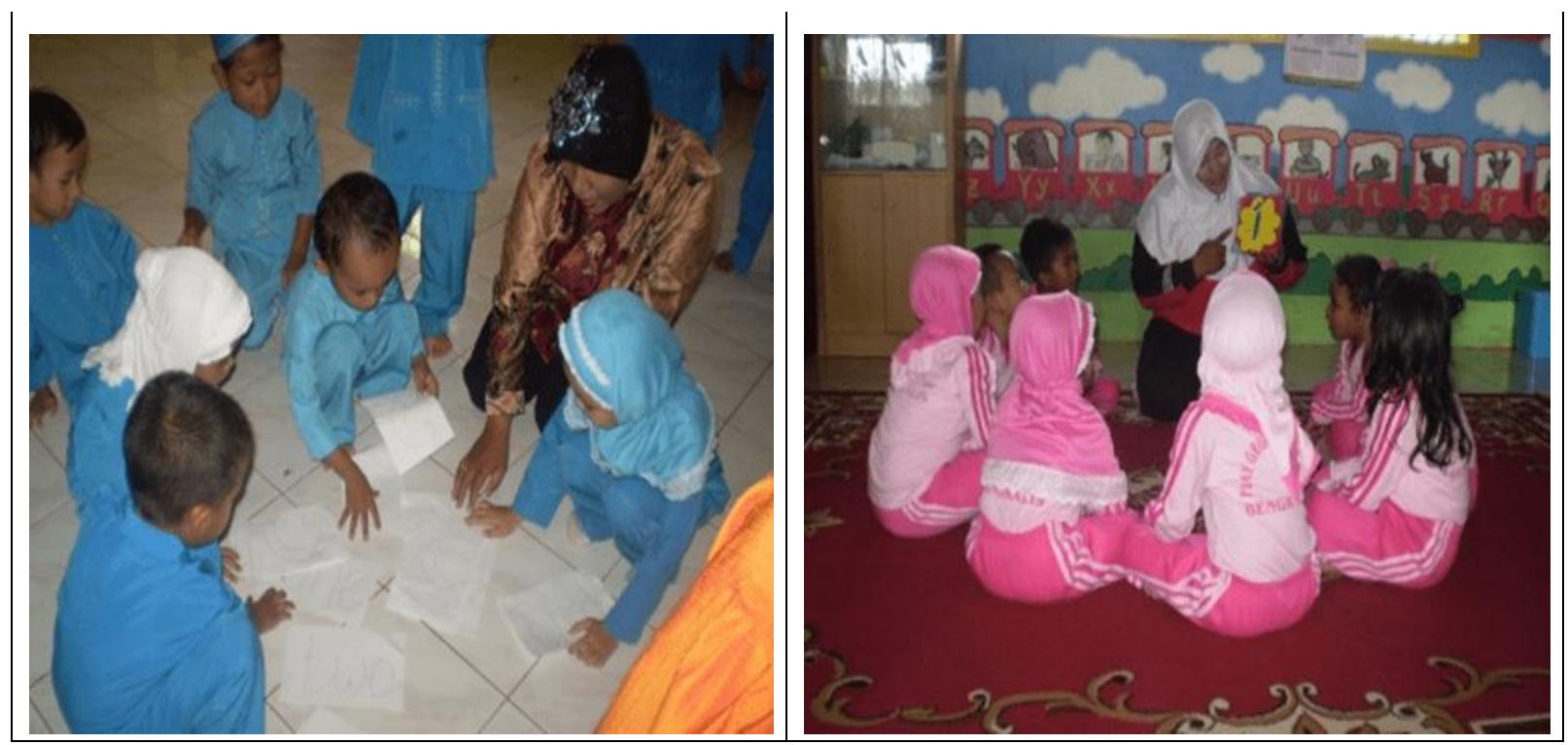

Gambar 3: Guru mengajar dengan Fun Game Teknik kepada Siswa Siswi PAUD

Kegiatan pembelajaran Fun Game teknik berupa permainan dan simulasi ini dimaksudkan untuk memberikan:

\section{I.Pengetahuan}

- Pengetahuan fungsi Bahasa (language function) Bahasa untuk berkomunikasi sederhana sehari hari.

- Penguasaan/pengetahuan kosa kata sederhana akan benda atau kata kata dalam Bahasa Inggris ditemui sehari-hari

- Pengenalan benda - benda yang ditemui sehari - hari dalam bahasa inggris termasuk cara pengucapan.

- Pengetahuan tentang tata cara berbahasa yang sopan (polite request) meliputi tentang tata cara bertanya dengan sopan, menyampaikan pendapat dengan sopan, meminta sesuatu dengan sopan dan menjawab pertanyaan dengan sopan.

\section{Keterampilan}

- Keterampilan mengajar Bahasa Inggris kepada siswa siswa PAUD dengan menggunakan teknik fun game

- Ketepatan mengajar guna meningkatkan kemampuan siswa PAUD dalam menguasai bahasa Inggris dengan menggunakan teknik Fun Game

- Menyimpulkan materi yang telah dipelajari dan menyampaikannya di kelas untuk melatih kemampuan memproduksi gagasan atau ide yang akan disampaikan.

\section{PELAKSANAAN DAN PEMBAHASAN}

Keberhasilan pelatihan Bahasa Inggris dengan teknik Fun Game ini dianalisis dengan memberikan tes untuk mengevaluasi keberhasilan program pengabdian serta mengevaluasi keberhasilan peserta pelatihan. Adapun aspek yang dievaluasi meliputi: 
PELATIHAN PENERAPAN TEKNIK FUN GAME PADA GURU GURU BAHASA INGGRIS PAUD KECAMATAN BENGKALIS

Erni Erni

Volume 1, No. 1, April 2021 hal. 89-101

DOI Artikel : 10.46306/jub.v1i1.18

\section{Pengetahuan}

- Pengetahuan akan tata krama penerapan bahasa inggris yang sesuai dengan fungsi bahasa untuk berkomunikasi

- Penguasaan / pengetahuan kosa kata akan benda - benda atau kata - kata dalam bahasa inggris yang ditemui sehari - hari.

\section{Keterampilan}

- Keterampilan dalam mengajar bahasa inggris kepada anak didik tingkat PAUD dengan menggunakan teknik fun game

- Ketyerampilan berbahasa Inggris dengan menggunakan teknik fun game

Kegiatan Pengabdian mencapai dua tujuan pelatihan yaitu:

Tujuan I. Meningkatkan kemampuan Bahasa Inggris dan keterampilan mengajarkan Bahasa Inggris guru guru PAUD mnelalui penerapan teknik Fun Game.

Evaluasi terhadap keberhasilan pelatihan dilakukan dalam bentuk test tertulis. Tes tertulis diberikan dalam bentuk pilihan ganda yang terdiri dari 40 soal untuk pre test dan post test. Data diambil dari nilai pre test dan post test terhadap 47 orang guru PAUD sebagai peserta pelatihan. Setelah diadakan pre test maka peserta diberikan treatment berupa penerapan teknik Fun Game selama 8 kali pertemuan kemudian diadakan post test. Deskripsi data dari kedua jenis test tertulis yaitu pre test dan post test dianalisis. Secara statistik hasil analisis data ditampilkan pada tabel dibawah ini.

\begin{tabular}{|c|c|c|}
\hline No & Pre Test & Post Test \\
\hline I & 50 & 68 \\
\hline 2 & 56 & 65 \\
\hline 3 & 60 & 68 \\
\hline 4 & 67 & 73 \\
\hline 5 & 56 & 66 \\
\hline 6 & 68 & 78 \\
\hline 7 & 55 & 69 \\
\hline 8 & 50 & 64 \\
\hline 9 & 60 & 69 \\
\hline 10 & 63 & 73 \\
\hline 11 & 70 & 74 \\
\hline 12 & 67 & 69 \\
\hline 13 & 66 & 70 \\
\hline 14 & 50 & 61 \\
\hline 15 & 64 & 68 \\
\hline 16 & 69 & 71 \\
\hline 17 & 70 & 77 \\
\hline 18 & 65 & 65 \\
\hline 19 & 60 & 65 \\
\hline 20 & 60 & 69 \\
\hline 21 & 65 & 70 \\
\hline 22 & 58 & 65 \\
\hline 23 & 50 & 63 \\
\hline 24 & 65 & 71 \\
\hline 25 & 70 & 74 \\
\hline
\end{tabular}


PELATIHAN PENERAPAN TEKNIK FUN GAME PADA GURU GURU BAHASA INGGRIS PAUD KECAMATAN BENGKALIS

Erni Erni

Volume 1, No. 1, April 2021 hal. 89-101

DOI Artikel : 10.46306/jub.v1i1.18

\begin{tabular}{|c|c|c|}
\hline 26 & 65 & 69 \\
\hline 27 & 69 & 73 \\
\hline 28 & 68 & 79 \\
\hline 29 & 50 & 64 \\
\hline 30 & 60 & 65 \\
\hline 31 & 40 & 50 \\
\hline 32 & 55 & 68 \\
\hline 33 & 68 & 75 \\
\hline 34 & 70 & 77 \\
\hline 35 & 70 & 76 \\
\hline 36 & 50 & 68 \\
\hline 37 & 55 & 64 \\
\hline 38 & 65 & 69 \\
\hline 39 & 60 & 63 \\
\hline 40 & 60 & 74 \\
\hline 41 & 58 & 65 \\
\hline 42 & 59 & 68 \\
\hline 43 & 65 & 75 \\
\hline 44 & 65 & 73 \\
\hline 45 & 55 & 69 \\
\hline 46 & 65 & 67 \\
\hline 47 & 65 & 71 \\
\hline
\end{tabular}

Tabel I. Hasil Perhitungan Data Pre Test dan Post Test

\section{Data Pre Test}

Berdasarkan data pada tabel I diatas, dari 47 orang guru didapat skor tertinggi 70 dan skor terendah 40. Distribusi frekuensi data Pre Test ditampilkan pada Tabel 2 berikut.

\begin{tabular}{|l|c|}
\hline SKOR & Frekuensi Absolut \\
\hline$\leq 40$ & $\mathrm{I}$ \\
\hline $45-50$ & 6 \\
\hline $5 \mathrm{I}-55$ & 5 \\
\hline $56-60$ & 12 \\
\hline $6 I-65$ & $1 \mathrm{I}$ \\
\hline $66-70$ & 12 \\
\hline Total & 47 \\
\hline
\end{tabular}

Tabel 2. Distribusi frekuensi data Pre Test

Berdasarkan uraian diatas dapat disimpulkan bahwa peserta pelatihan yang mendapat skor rendah $\leq 40$ ada I orang dan sampel yang mendapat skor cukup baik 66-70 ada 14 orang dan sisanya tersebar dibeberapa rentangan skor.

\section{Data Post Test}

Data post test diambil setelah 8 kali pertemuan. Berdasarkan data pada tabel I diatas dibawah, skor tertinggi 79 dan skor terendah 50. Distribusi frekuensi data Post Test adalah sebagai berikut.

\begin{tabular}{|l|c|}
\hline Skor & Frekuensi Absolut \\
\hline$\leq 50$ & 1 \\
\hline $55-60$ & 2 \\
\hline
\end{tabular}


PELATIHAN PENERAPAN TEKNIK FUN GAME PADA GURU GURU BAHASA INGGRIS PAUD KECAMATAN BENGKALIS

Erni Erni

Volume 1, No. 1, April 2021 hal. 89-101

DOI Artikel : 10.46306/jub.v1i1.18

\begin{tabular}{|l|l|}
\hline $6 I-65$ & 12 \\
\hline $66-70$ & 15 \\
\hline $7 I-75$ & 12 \\
\hline $76-80$ & 5 \\
\hline Total & 47 \\
\hline
\end{tabular}

Tabel 3. Distribusi frekuensi data Post Test

Berdasarkan uraian diatas dapat disimpulkan bahwa dari 47 orang guru yang mendapat skor dibawah lima puluh atau sama dengan 50 adalah I orang dan yang mendapat skor baik adalah 5 orang. Disimpulkan bahwa terjadi peningkatan hasil post test setealh diberi treatment.

Tujuan 2. Untuk meningkatkan kemampuan dan keterampilan berbahasa Inggris siswa PAUD dengan teknik Fun Game.

Data keterampilan berbahasa berdasarkan fungsi bahasa didapat dengan melakukan tes oral. Setelah hasil tes speaking/ berbicara diperoleh, maka dilakukan peniliaian terhadap kemampuan berbahasa yang diproduksi sesuai dengan fungsi bahasa. Penilaian yang tepat dan sesuai diterapkan dalam megukur keberhasilan pelatihan ini karena metode penilaian juga mempengaruihi pencapaian hasil belajar. Ada empat system penialain yang diterapkan yaiu:

a. Exact match: Satu point untuk setiap jawaban yang yang benar dalam urutan.

b. Classic: Satu point untuk kecocokan yang persis sama, satu point jika kalimat sebelumnya benar dalam urutan, satu point jika kalimat berikutnya dalam urutan, dan satu point jika kalimat adalah yang terakhir dalam urutan dan tidak ada kalimat yang diluar urtan.

c. Added value: Sama seperti klasik, tetapi ada point untuk jawaban yang tepat diluar urutan.

d. Full pair: Nilai didapat dari jumlah point sebelumnya dan point (Glenn, 20I0)

Data diambil dari tes speaking selama kegiatan pelatihan. Partisipant yang merupakan siswa PAUD berjumlah 40 orang dan setiap siswa membutuhkan rata - rata waktu 7-15 menit untuk tes lisan ini. Data ini diambil dalam pre test dan post test yang melingkupi vocabulary, pronunciation, dan fluency. Setelah diadakan pre-test peserta diberi treatment dengan menerapkan teknik fun game selama 6 kali pertemuan kemudian diadakan post-test. Deskripsi data dari kedua jenis tes oral yaitu pre test dan post test dicantumkan pada table 4 dibawah.

\begin{tabular}{|c|c|c|}
\hline No & Pre Test & Post Test \\
\hline 1 & 80 & 85 \\
\hline 2 & 75 & 80 \\
\hline 3 & 75 & 80 \\
\hline 4 & 80 & 85 \\
\hline 5 & 75 & 80 \\
\hline 6 & 70 & 75 \\
\hline 7 & 70 & 80 \\
\hline 8 & 65 & 70 \\
\hline 9 & 60 & 70 \\
\hline 10 & 70 & 75 \\
\hline 11 & 70 & 75 \\
\hline 12 & 60 & 75 \\
\hline
\end{tabular}


PELATIHAN PENERAPAN TEKNIK FUN GAME PADA GURU GURU BAHASA INGGRIS PAUD KECAMATAN BENGKALIS

Erni Erni

Volume 1, No. 1, April 2021 hal. 89-101

DOI Artikel : 10.46306/jub.v1i1.18

\begin{tabular}{|c|c|c|}
\hline 13 & 60 & 70 \\
\hline 14 & 60 & 70 \\
\hline 15 & 50 & 65 \\
\hline 16 & 50 & 70 \\
\hline 17 & 40 & 65 \\
\hline 18 & 60 & 65 \\
\hline 19 & 40 & 70 \\
\hline 20 & 50 & 70 \\
\hline 21 & 75 & 80 \\
\hline 22 & 80 & 85 \\
\hline 23 & 75 & 85 \\
\hline 24 & 55 & 75 \\
\hline 25 & 40 & 60 \\
\hline 26 & 75 & 75 \\
\hline 27 & 55 & 65 \\
\hline 28 & 40 & 60 \\
\hline 29 & 65 & 70 \\
\hline 30 & 60 & 70 \\
\hline 31 & 60 & 75 \\
\hline 32 & 75 & 85 \\
\hline 33 & 55 & 75 \\
\hline 34 & 80 & 85 \\
\hline 35 & 50 & 65 \\
\hline 36 & 75 & 75 \\
\hline 37 & 40 & 55 \\
\hline 38 & 50 & 60 \\
\hline 39 & 75 & 85 \\
\hline 40 & 60 & 70 \\
\hline
\end{tabular}

Tabel 4. Hasil Perhitungan Data Pre Test dan Post Test

\section{Data Pre Test}

Berdasarkan pada tabel diatas, dari 40 orang sampel didapat skor tertinggi 80 dan skor terendah 40 .

Distribusi frekuensi Pre Test ditampilkan pada tabel berikut.

\begin{tabular}{|l|c|}
\hline Skor & Frekuensi Absolut \\
\hline$\leq 40$ & 5 \\
\hline $45-50$ & 5 \\
\hline $5 I-55$ & 3 \\
\hline $56-60$ & 8 \\
\hline $6 I-65$ & 2 \\
\hline $66-70$ & 4 \\
\hline $7 I-75$ & 9 \\
\hline $76-80$ & 4 \\
\hline Total & 40 \\
\hline
\end{tabular}

Tabel 5. Distribusi Frekuensi data Pre Test

Berdasarkan uraian diatas dapat disimpulkan bahwa sampel yang mendapat skor paling rendah $\leq 40$ ada 5 orang dan sampel yang mendapat skor sangat baik $76-80$ ada 4 orang dan sisanya tersebar dibeberapa rentangan skor. 
PELATIHAN PENERAPAN TEKNIK FUN GAME PADA GURU GURU BAHASA INGGRIS PAUD KECAMATAN BENGKALIS

Erni Erni

Volume 1, No. 1, April 2021 hal. 89-101

DOI Artikel : 10.46306/jub.v1i1.18

\section{Data Post Test}

Data post test diambil setelah 6 kali pertemuan. Berdasarkan data pada tabel dibawah, skor tertinggi 85 dan skor terendah 55. Distribusi frekuensi data Post Test adalah sebagai berikut

\begin{tabular}{|l|c|}
\hline Skor & Frekuensi Absolut \\
\hline$\leq 55$ & 1 \\
\hline $56-60$ & 3 \\
\hline $61-65$ & 6 \\
\hline $66-70$ & 10 \\
\hline $71-75$ & 9 \\
\hline $76-80$ & 5 \\
\hline $81-85$ & 6 \\
\hline Total & 40 \\
\hline
\end{tabular}

Table 6. Distribusi frekuensi data Post Test

Berdasarkan uraian diatas di dapat bahwa dari 40 orang sampel yang mendapat skor dibawah 55 adalah I orang dan yang mendapatkan skor baik sekali diatas 8 ladalah 6 orang.

Pelaksanaan pengabdian pada masyarakat ini menunjukkan bahwa teknik Fun Game dapat meningkatkan keterampilan guru PAUD di Kabubaten Bengkalis dalam mengajar Bahasa Inggris. Penemuan ini juga menunjukkan bahwa pengetahuan guru - guru terhadap tata karma dan fungsi bahasa serta kosa kata dengan penerapan teknik Fun Game memberi pengaruh yang signifikan terhadap peningkatan keterampilan mengajar guru dan hasil belajar Bahasa Inggris siswa PAUD terutama dalam penguasaan kosa kata serta pengucapannya (pronunciation).

Metode pembelajaran berbasis game dapat mengubah pembelajaran membosankan menjadi proses pembelajaran yang nyata dan aktif, dapat menarik perhatian dan minat siswa, efektivitas dan motivasi belajar yang lebih tinggi (Wu, 2018). Guru Bahasa Inggris PAUD mengajar dengan lebih efektif, meneyenangkan dan inovative jika menggunakan teknik fun game dalam proses belajar mengajar. Anak didik mereka lebih termotivasi dan tertarik dengan teknik tersebut sehingga memberikan pengaruh yang signifikan terhadap hasil belajarnya.

\section{KESIMPULAN DAN SARAN}

Berdasarkan hasil analisis data serta pembahasan yang dilakukan pada bagian sebelumnya, maka dapat diambil beberapa kesimpulan sebagai berikut:

I. Strategi pelatihan dengan teknik fun game dapat meningkatkan keterampilan guru Bahasa Inggris PAUD dalam mengajar Bahasa Inggris.

2. Dengan menerapkan teknik Fun Game dalam proses belajar mengajar dapat meningkatkan hasil belajar Bahasa Inggris siswa TK se-kabupaten Bengkalis.

Teknik Fun Game adalah strategi mengajar yang menyenangkan. Anak anak pelajar Bahasa asing dapat mengabstraksi pola baru dari input yang mereka terima tanpa instruksi langsung dari guru mereka.

Dengan teknik Fun Game terbukti peserta pelatihan antusias belajar dan senang dalam mempelajari bahasa inggris. Berhubung secara empiris telah terbukti bahwa teknik fun game mampu meningkatkan 
PELATIHAN PENERAPAN TEKNIK FUN GAME PADA GURU GURU BAHASA INGGRIS PAUD KECAMATAN BENGKALIS

Erni Erni

Volume 1, No. 1, April 2021 hal. 89-101

DOI Artikel : 10.46306/jub.v1i1.18

keterampilan guru dalam mengajar serta memberikan pengaruh signifikan terhadap hasil belajar siswa PAUD dalam penguasaan Bbahasa Inggris. Maka disarankan kepada guru - guru Bahasa Inggris PAUD untuk dapat menerapkan strategi mengajar yang ringan dan menyenangkan dalam meningkat kemampuan berbahasa Inggris yang tepat untuk siswa PAUD.

Berhubung penelitian ini terbatas pada peningkatan pengetahuan dan keterampilan berbahasa, maka disarankan kepada peneliti berikutnya untuk menerapkan strategi yang lebih efektif untuk meningkat keterampilan mengajar guru bahasa Inggris serta hasil belajar bahasa Inggris siswa PAUD.

\section{DAFTAR PUSTAKA}

Adiputra, Kristian, 2012. Mengurai Benang Kusut Pembelajaran Bahasa Inggris. Radar Lampung. Graha Pena Lampung (redaksi@radarlampunh.co.id)

Aoestyoowati, Redjeky. 2010. Fun English Game \& Activities for You. Jakarta. Bhuhana Ilmu Populer. Chamot, Anna Uhl. at al. 1999. The Learning Strategies. New York: Longman Inc.

DISKOMINFO. 2019. STATISTIK SEKTORAL KABUPATEN BENGKALIS. edited by Gholap.Asip. Bengkalis: Diskominfo Bengkalis.

DISKOMINFO. (20I9). STATISTIK SEKTORAL KABUPATEN BENGKALIS. edited by Gholap.Asip. Bengkalis: Diskominfo Bengkalis.

Edmundo, J. More. (1988). USING PICTURE CREATIVELY. Washington: English Language Program Division Bureau of Education and Cult Affair.

Erni. (2007). PELATIHAN BAHASA INGGRIS DENGAN TEKNIK GAME UNTUK MENINGKATKAN KEMAMPUAN BAHASA INGGRIS CALON TKI DI KOTA PEKANBARU. Laporan Penelitian (unpublished) Universitas Riau

Finochiaro, Mary. (1974). ENGLISH AS A SECOND LANGUAGE FROM THEORY TO PRACTICE. USA: Regent Publishing Company. Inc.

Fulcher, Glenn. 2010. Practical Language Testing. Ist ed. London UK: Hodder Education, An Hachette UK Company.

Lander, Emma. (20I8). I0 FUN ESL GAMES AND ACTIVITIES FOR TEACHING KIDS ENGLISH ABROAD. https://www.gooverseas.com.

Uberman, Agnieska. (2010). THE USE OF GAMES. http:/Indoline.org/ld-indept/Teaching Ur, Penny. (1977). A COURSE IN LANGUAGE TEACHING. CAMBRIDGE. UNIVERSITY PRESS. Suh, S., Kim, S. W., \& Kim, N. J. (20I0). EFFECTIVENESS OF MMORPG-BASED INSTRUCTION IN ELEMENTARY ENGLISH EDUCATION IN KOREA. Journal of Computer Assisted Learning, 26(5), 370-378. https://doi.org/I 0. I I I I/j. I365-2729.2010.00353.x

Uberman, Agnieska. (2010). THE USE OF GAMES. http:/Indoline.org/ld-indept/Teaching Ur, Penny. (1977). A COURSE IN LANGUAGE TEACHING. CAMBRIDGE. UNIVERSITY PRESS. Wu, T. T. (20I8). IMPROVING THE EFFECTIVENESS OF ENGLISH VOCABULARY REVIEW BY INTEGRATING ARCS WITH MOBILE GAME-BASED LEARNING. Journal of Computer Assisted Learning, 34(3), 3 I5-323. https://doi.org/I0.I I I //jcal. 2244 